\title{
THE CLINICAL CONTROL OF RED CELL LOSS IN BURNS
}

\author{
BY \\ ELIZABETH TOPLEY AND D. MACG. JACKSON \\ From the Medical Research Council Industrial Injuries and Burns Research Unit, Birmingham Accident \\ Hospital
}

(RECEIVED FOR PUBLICATION APRIL 14, 1956)

The purpose of this paper is to define the red cell loss in burned patients when the haemoglobin and blood volume are kept above $75 \%$ of normal. Our aim has been to present the results in a manner which will be useful to surgeons managing the blood transfusion of these patients. With this in view the predictability of red cell loss has been reviewed in relation to the areas of partly and completely burned skin, to haematocrits, haemoglobin values, and red cell counts on the peripheral blood, to red cell volume estimations, and to clinical signs such as haemoglobinuria.

The development of anaemia in badly burned patients has been recognized by surgeons for many years, and has been attributed to obvious external loss such as bleeding granulations or blood loss at operation. An impaired rate of red cell formation has been suggested as one cause of the more chronic anaemia (Cope, 1947). Only recently has an unexplained internal disappearance of red cells been considered to play a major role. The work of Shen and Ham (1943), Brown (1946), and more recently Davies and Topley (1956) shows that the immediate effect of heat is responsible for red cell loss amounting on average to only about 5 to $10 \%$ of the red cell volume. The pioneer work of Moore, Peacock, Blakely, and Cope (1946) has been followed by later evidence (Davies and Topley, 1956) which agrees that there is a further unexplained internal disappearance of patients' and transfused cells that may show as early as eight hours after injury and continue for many weeks. For example, one of Moore's cases (Moore et al., 1946) showed a loss of about 300 $\mathrm{ml}$. of packed red cells a day for the first three days, and required frequent blood transfusions for 10 weeks. This massive unexplained disappearance of red cells after extensive burns presents surgeons with such clinical questions as, "When does this destruction occur?" "How great is it ?", and "How urgent is its replacement?"

\section{METHODS}

Patients

The data have been obtained from 150 cases treated in the Birmingham Accident Hospital Burns Unit between 1952 and 1956. They were selected so as to include a preponderance of burns involving 15$50 \%$ of the body surface, that is, such patients in whom previous experience had shown that anaemia was likely to develop (Braithwaite and Moore, 1948). Occasional smaller burns have been included in the study, and during the last year some of the more extensive burns with poor prognosis have been studied in detail.

\section{Measurement of the Burn}

The figures given for the total area burned and the area of full-thickness skin-loss are percentages of the total surface area of the body. "Full-thickness skinloss" implies complete destruction of all epithelial elements in the skin, so that epithelialization can only occur from the edge of the wound or by grafting. The area of total skin-loss excludes areas burned to the degree of erythema only, and the method of estimation is based on that of Berkow $(1924,1931)$. Areas of full-thickness skin-loss are checked two to three weeks after injury when granulations appear.

\section{Peripheral Blood Findings}

Because it was rare to find gross changes in the interrelationship between haemoglobin, haematocrit, and red cell count, these values can be used interchangeably in our calculations of blood loss according to convenience.

We used haematocrits during the shock stage because they were being carried out about hourly for clinical reasons. We used red cell counts in our calculations of blood loss because the data were being used also for calculating the differential disappearance of patients' and transfused cells reported elsewhere (Davies and Topley, 1956). The normal haemoglobin and red cell count for age and sex has been taken from Wintrobe (1951).

Haemoglobin.-Haemoglobin was estimated as oxyhaemoglobin using the Spekker photo-electric colori- 
meter, and checking the calibration by a monthly supply of blood of known haemoglobin content.

Red Cell Counts.-Red cell counts were made by visually counting at least 1,200 cells.

Haematocrit.-In the absence of a venous haematocrit the capillary haematocrit was used as a guide to the venous haematocrit. During shock treatment, most haematocrits were estimated on ear capillary blood. Samples were taken into a specially designed small haematocrit tube and spun at high speed on an angle centrifuge for about 10 minutes. At the time of blood volume estimations venous blood was taken and the haematocrit estimated in Wintrobe tubes at a speed of 3,000 r.p.m. in a centrifuge of head radius $15 \mathrm{~cm}$. for 55 minutes. Comparison of the two methods showed that the angle centrifuge gave a reading about $0.5 \%$ higher than the Wintrobe method and a greater variation $( \pm 3 \%)$. In order to allow for "trapped" plasma in the haematocrit after centrifuging, the following further figures were subtracted from the reading to get the true venous haematocrit (Chaplin and Mollison, 1950):

\begin{tabular}{c|c}
\hline Haematocrit Reading (\%) & Subtract for Trapped Plasma (\%) \\
\cline { 2 - 2 } $20-29$ & 2 \\
$30-39$ & $2 \cdot 5$ \\
$40-49$ & $3 \cdot 0$ \\
$50-59$ & $3 \cdot 5$ \\
$60-69$ & $4 \cdot 0$ \\
\hline
\end{tabular}

venous haematocrit, assuming a normal body/venous haematocrit ratio (Reeve, 1948).

Blood volume was calculated from red cell volume and venous haematocrit, assuming a normal body/ venous haematocrit ratio (Reeve, 1948).

The normal values have been taken from a figure (Davies and Topley, 1956) summarizing published data. Fig. 1 is a more recent version which includes "normal" follow-up results on patients in the Birmingham Accident Hospital. The height is often a more precise guide than age or weight. Individual patients, especially the adolescent, the very muscular, the very thin, or the very fat, may have red cell volumes more than $20 \%$ outside the normal value for height.

\section{Estimates of Red Cell Loss}

The words " red cell loss" used here cover all forms of red cell loss, whatever the cause ; thus, it may include haemorrhage, internal red cell destruction, and impaired rate of red cell formation.

Shock Stage.-During the shock stage, because the total blood volume frequently varies, the peripheral blood findings are not a reliable guide to red cell loss. To estimate red cell loss we have therefore relied entirely on red cell volume studies.

The red cell loss is the difference between the expected "normal" red cell volume (Fig. 1) plus the volume of red cells transfused and the actual red cell
The normal venous haematocrit and the variation round the normal has not been accurately defined in children or adults. The data in Fig. 1 are based on a variety of sources (Seckel, 1930; Gibson and Evans, 1937 ; Brines, Gibson, and Kunkel, 1941 ; Russell, 1949 ; Wintrobe, 1951).

\section{Blood Volumes}

Red cell volumes were carried out by injecting labelled red cells intravenously and measuring their dilution in the blood stream by taking a blood sample from another vein after mixing had occurred. The accuracy of this method in burned patients is still under critical review (Davies and Topley, 1956). The possibility of false low or false high results should be continually borne in mind, particularly during the first four days after injury.

The red cell volume is the dilution of labelled cells multiplied by venous haematocrit. Radioactive phosphate (Reeve and Veall, 1949), radioactive chromate (Mollison and Veall, 1955), and group $\mathbf{N}$ cells transfused to group $M$ patients (Reeve, 1948) have been used as labelling agents. The red cell volume has also been derived from the Evans blue plasma volume and

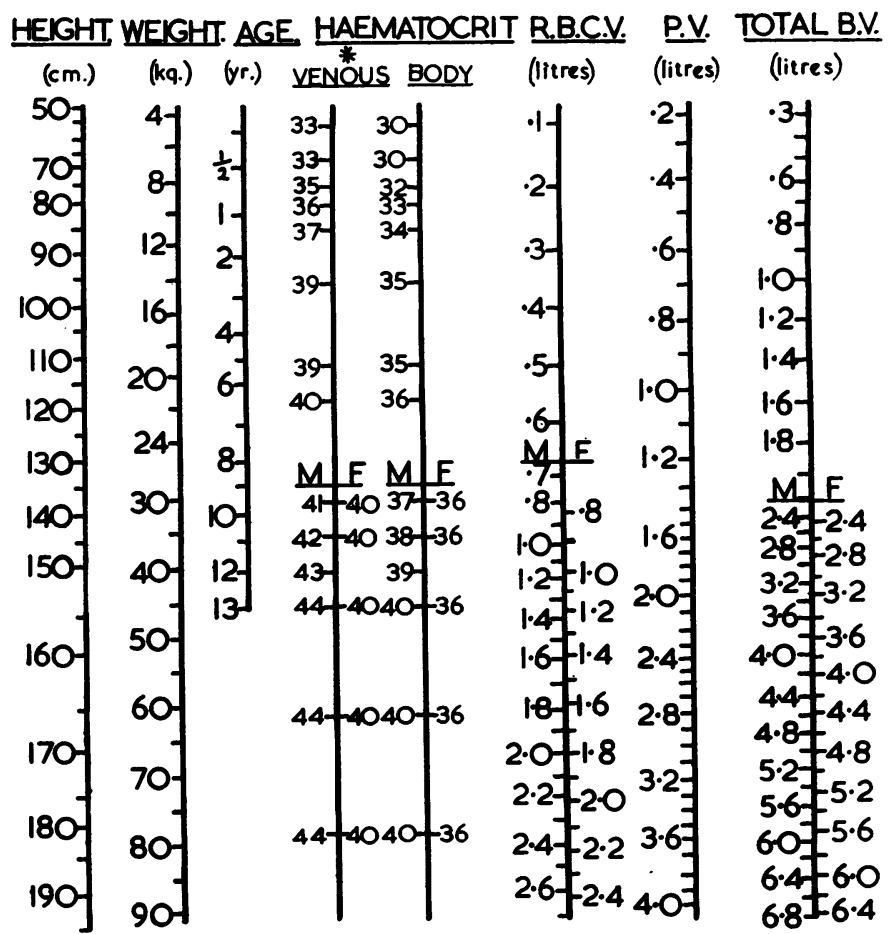

FIG. 1.-Average normal values for plasma volume, red cell volume, and blood volume for different ages, weights, and heights. *The figures for venous haematocrit have been corrected for trapped plasma (see text). The samples were centrifuged for 55 minutes at 3,000 r.p.m. 
volume found using one of the methods described above. The loss can be expressed as a percentage of the expected normal value, namely,

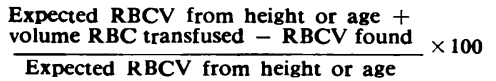

The volume of red blood cells transfused is taken as one-third of the citrated blood transfused, because on an average transfused blood has a haematocrit of $33 \%$.

Admission to Operation.-From admission to operation blood loss has been calculated from peripheral blood findings.

The changes in the peripheral blood can be used as a guide to red cell loss if one assumes that the patient had a normal red cell count for his age at the time of the accident, and that the blood volume had returned to normal by the time of the first operation two or three weeks later. Twenty red cell volumes after the first week and before operation by the $\mathbf{P}^{32}$, $\mathrm{Cr}^{51}$, or Evans blue methods showed on average a normal blood volume. There was, however, a fairly wide scatter of results: 15 out of 20 patients had a blood volume within $25 \%$ of normal. The red cell loss is the difference between the expected normal and the pre-operative red cell count expressed as a percentage of the expected normal red cell count. Allowance has to be made for blood transfusion given at any time before operation. The expected effect on the patient's red cell count by a blood transfusion is the number of red cells transfused divided by the normal blood volume for the age or height. The number of cells transfused has been estimated on bottles transfused in this hospital by testing specific gravity, weight, and red cell count of the bottled blood before and after transfusion. A one-pint bottle in which about $500 \mathrm{ml}$. of citrated blood has been transfused is equivalent to about $2 \times 10^{9}$ red cells. The expected red cell count from transfused cells therefore becomes:

$2 \times 10^{9} \times$ volume of citrated blood transfused in $\mathrm{ml}$. $500 \times \mathrm{BV}$ in c. mm. $\times 10^{6}$

At Operation.-Red cell loss at operation has been calculated in a number of different ways:

(1) By Swab Weighing.-Gauze swabs of predetermined weight were used and reweighed after use. The difference in weight was largely due to whole blood loss of specific gravity 1.04. Moistened swabs were not used and a rubber sheet was laid under the patient. Generous use of large swabs reduced uncollected blood loss to a minimum (Baronofsky, Treloar, and Wangensteen, 1946).

(2) By Red Cell Volume Studies.-A red cell volume estimation was occasionally performed both before and after a grafting operation.

(3) Peripheral Blood Findings.-If the blood volume was normal on the day of the tests the difference between the last pre- and first post-operative red cell count is a guide to red cell loss, after allowing for the effect of blood transfused. The calculation is exactly similar to that described above for blood loss from admission to operation, except that the preoperative red cell count is taken instead of the expected normal for the age. In most cases there was not a great difference between the red cell count one day after operation and a few days later, the results described below being essentially similar if the red cell count the day after operation or the lowest figure during the ensuing days was taken as the postoperative result.

Between and After Operations.-Blood loss between and blood loss after operations have been calculated from peripheral blood findings.

For blood loss between operations the first postoperative red cell count has been compared with the count before the next operation. For the loss after operation the first post-operative count has been compared with a count on discharge from hospital.

\section{RESULTS}

The average red cell loss at different periods after admission is shown in Fig. 2. The greatest amount of blood is lost during operation; in these studies, when more than one skin-grafting operation has been necessary, the sum of the blood loss in all operations has been added together: the average loss and also the amount transfused during this part of treatment has amounted to $135 \%$ of the patient's red cells (Fig. 2). The next most important period in this respect is the two to three weeks from injury to operation : red cell loss during this time has averaged $45 \%$ of the red cells. Part of this loss occurs during the shock stage, arbitrarily fixed at the first $\mathbf{4 8}$ hours, and this is of special importance, not so much due to the anaemia produced, but because failure to appreciate the degree of red cell destruction may hide a severe oligaemia which may prove fatal. By the time of discharge from hospital the patient's

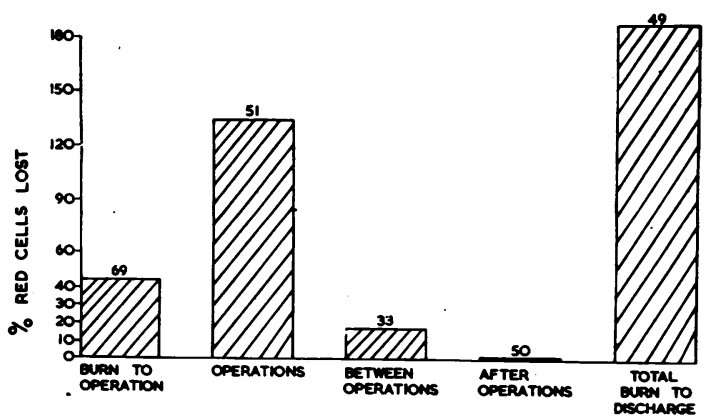

Fig. 2.-Average red cell loss, based on peripheral blood findings, at different stages after injury. Figures above each column refer to numbers of patients studied. 
"EARLY" CASES
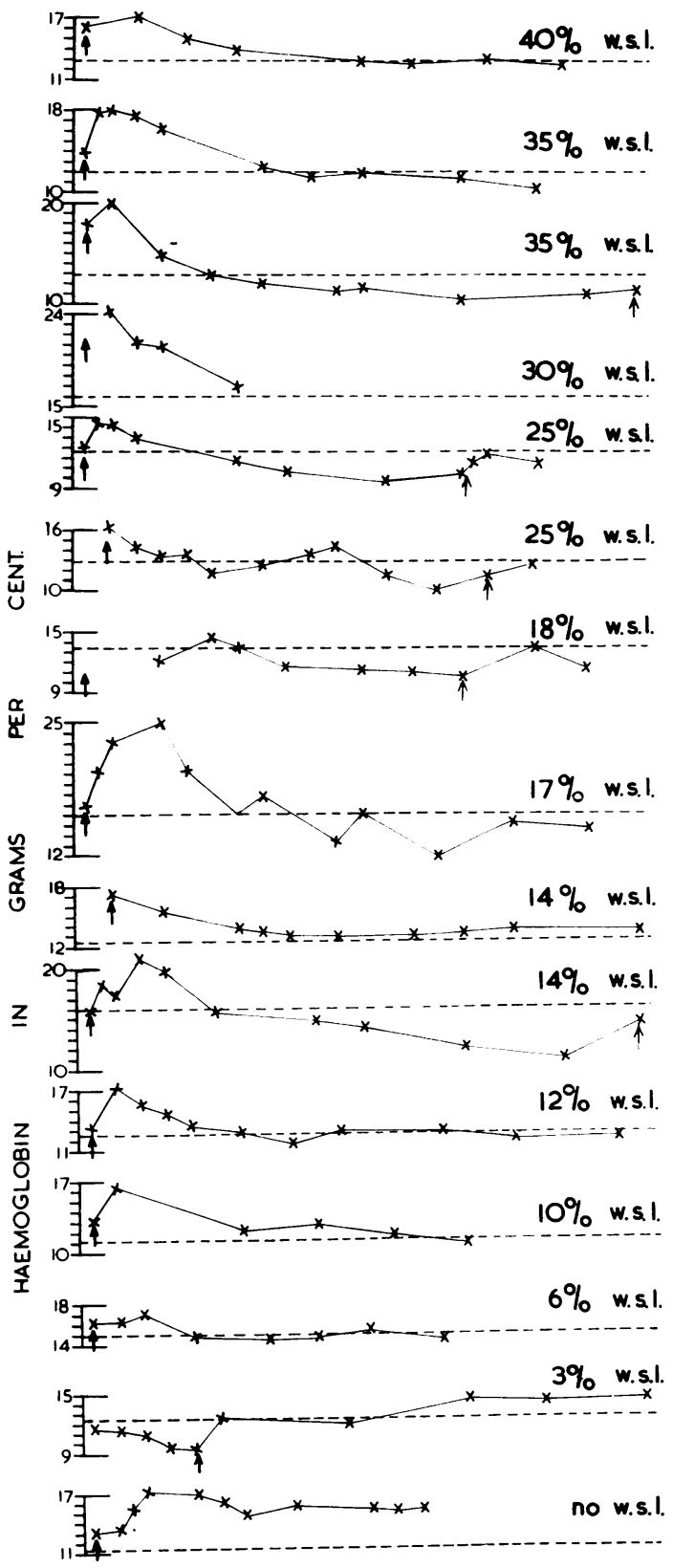

1234567891011121314151617181920212223 DAYS AFTER BURNING

W.S.L.= AREA OF WHOLE SKIN LOSS

$\uparrow=$ BLOOD TRANSFUSIONS.

"LATE" CASES

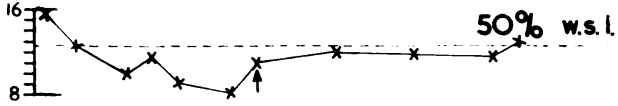

$36 \%$ w. s. I.

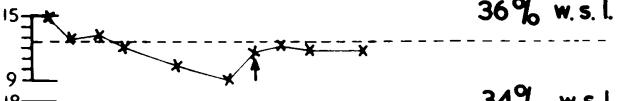

$34 \%$ w.s.

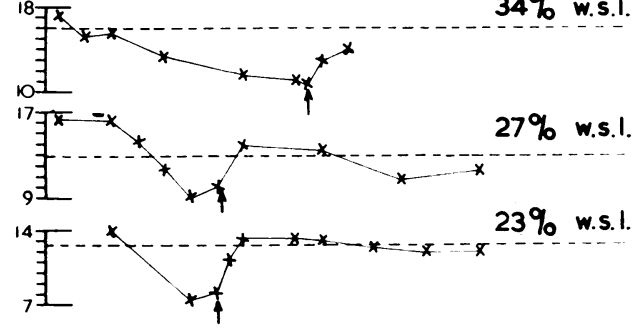

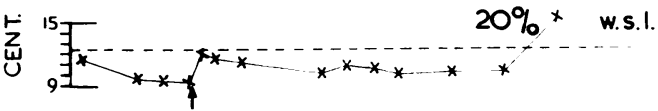

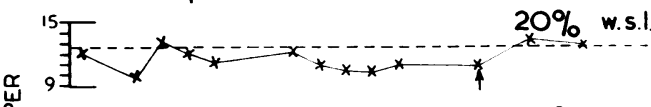

感
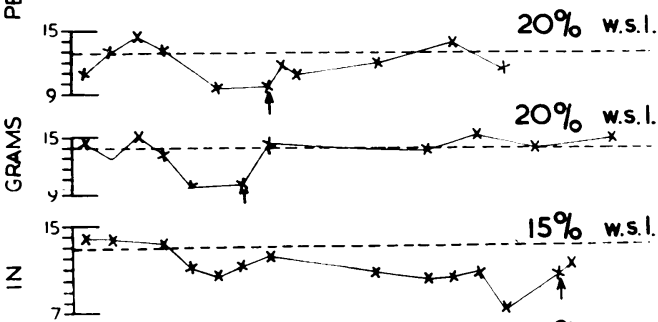

$15 \%$ w.s. 1

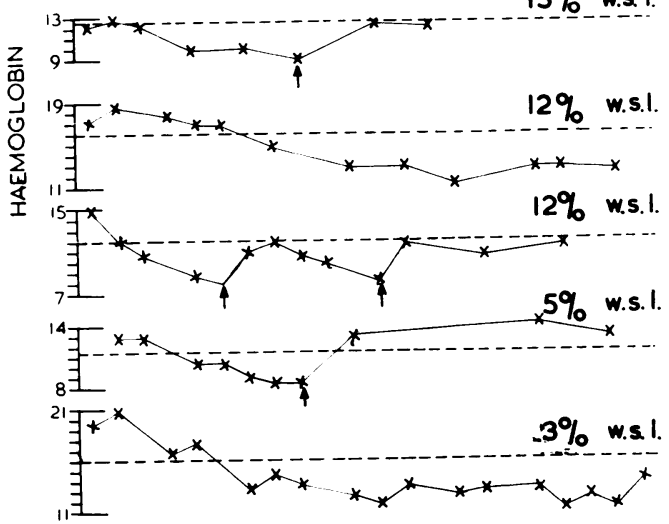

12345678910111213141516171819202122 DAYS AFTER BURNING - NORMAL Hb. FOR AGE.

Fic. 3.-Haemoglobin charts of patien:s given blood " early" and "late." w.s.l.=area of whole skin-kss; $\uparrow=$ blood transfusion; - normal haemoglobin for age. 
total red cell loss averaged $185 \%$ of the patient's red cells. The extent of red cell loss is described below in the order in which it occurs.

\section{Red Cell Loss from Burn to Operation}

Guide to Red Cell Loss During Whole Period from Burn to Operation.-Evidence is presented on how the daily haemoglobin changes and the area of the burn have been used as guides in assessing more precisely the red cell loss in individual patients.

Daily Haemoglobin.-Daily haemoglobin estimations show a characteristic pattern. The changes in the peripheral blood are shown in Fig. 3. Each chart represents one patient, and the patients are ranked in order of decreasing area of full-thickness skin-loss. The level remained steady or even rose during the first day or two, fell sharply, and then often continued to fall until operation two to three weeks after admission. If a blood transfusion had been given on admission (Fig. 3 " early") the haemoglobin level was at first high and fell towards and often below normal. If blood transfusion was withheld until anaemia developed (Fig. 3 "late") the haemoglobin level, at first slightly above or near normal, fell to levels below normal, often reaching $20 \%$ below normal between the sixth and tenth day after admission. Comparison of these haemoglobin curves (Fig. 3 "late") with our red cell volume data (Fig. 4) shows that, during the first two days when the haemoglobin concentration in the peripheral blood was near normal, red cell loss had already occurred. The haemoglobin therefore often underestimated the red cell loss. As shown under "methods" above, from the seventh day onward the haemoglobin was a moderately good guide to the red cell loss, and a low figure due to excessive haemodilution was rare.

Since the rate of red cell loss is so very variable from patient to patient, we emphasize the need for serial haemoglobin estimations in order to know in individual patients when the haemoglobin, and therefore probably the red cell volume, has fallen to levels that may indicate the need for a further blood transfusion. It is important to emphasize the limited value of these results during the first few days after injury.

Area of Full-thickness Skin-loss.-Fig. 5 is a scatter diagram showing the relationship between the estimated area of full-thickness skin-loss and the red cell loss between burn and operation calculated from the changes in the peripheral blood.

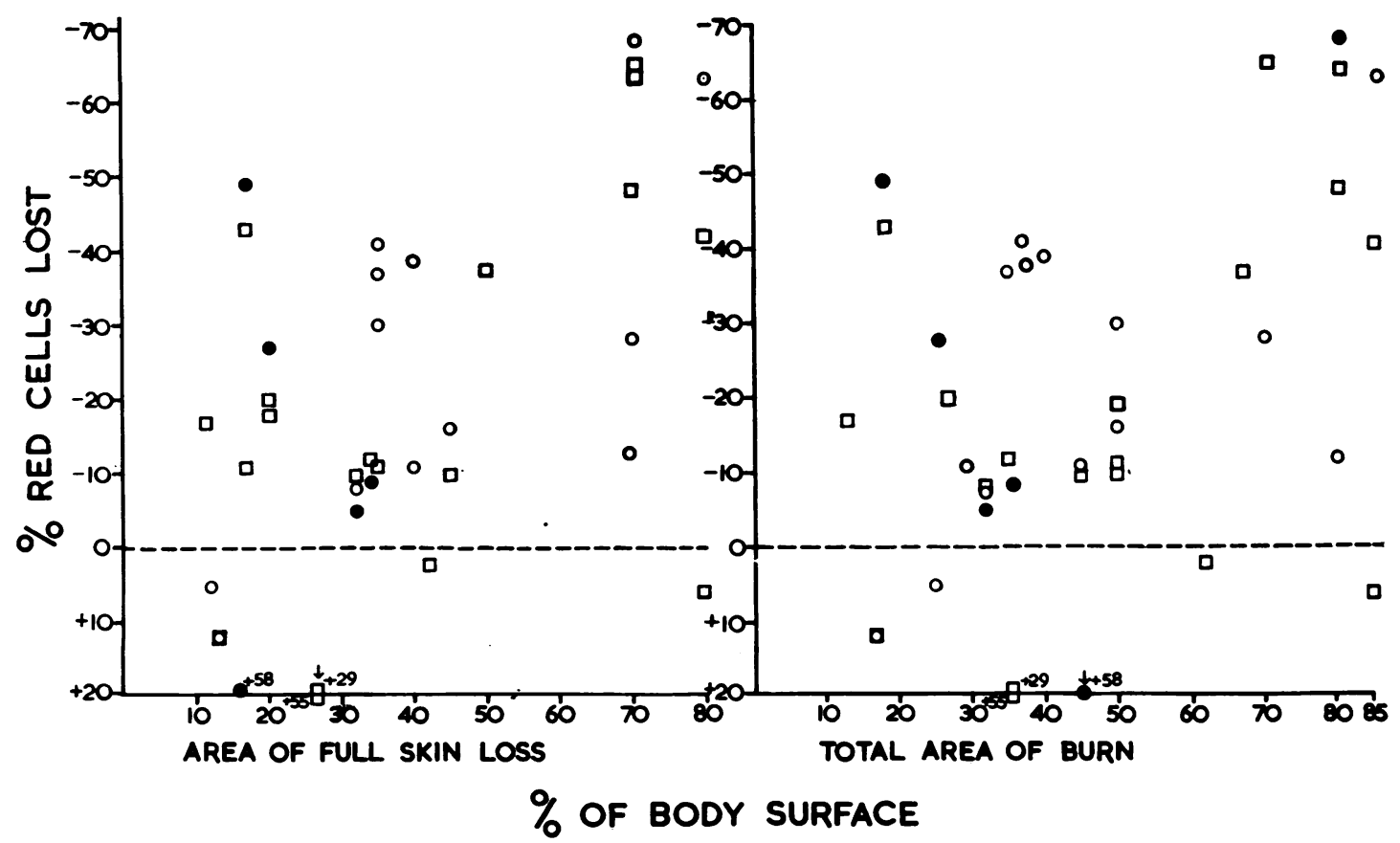

Fig. 4.-Ret cell loss, based on ret cell volume studies, 12-48 hours after injury related to (a) area of full-thickness skin-loss (36 cases), (b) total area of burn (38 cases). $\square=\mathbf{P}^{32}$. $O=\mathrm{G}^{51}$. $\quad \boldsymbol{Q}=$ Evans blue. 
The rationale of our present transfusion policy is based on these results.

(1) Full-thickness skin-loss up to $10 \%$ of the body surface: it can be seen from Fig. 5 that no cases $(0 / 16)$ showed a red cell loss of more than $40 \%$ of their red cells from burn to operation. In only half the patients did the loss exceed $25 \%$ of the red cells. In about half the cases therefore no blood transfusion was required at any time before operation. On the basis of this data we do not give a blood transfusion on admission to patients with less than $10 \%$ full-thickness skin-loss. A blood transfusion is given when the haemoglobin has fallen below 75 to $80 \%$ of the expected normal for the age.
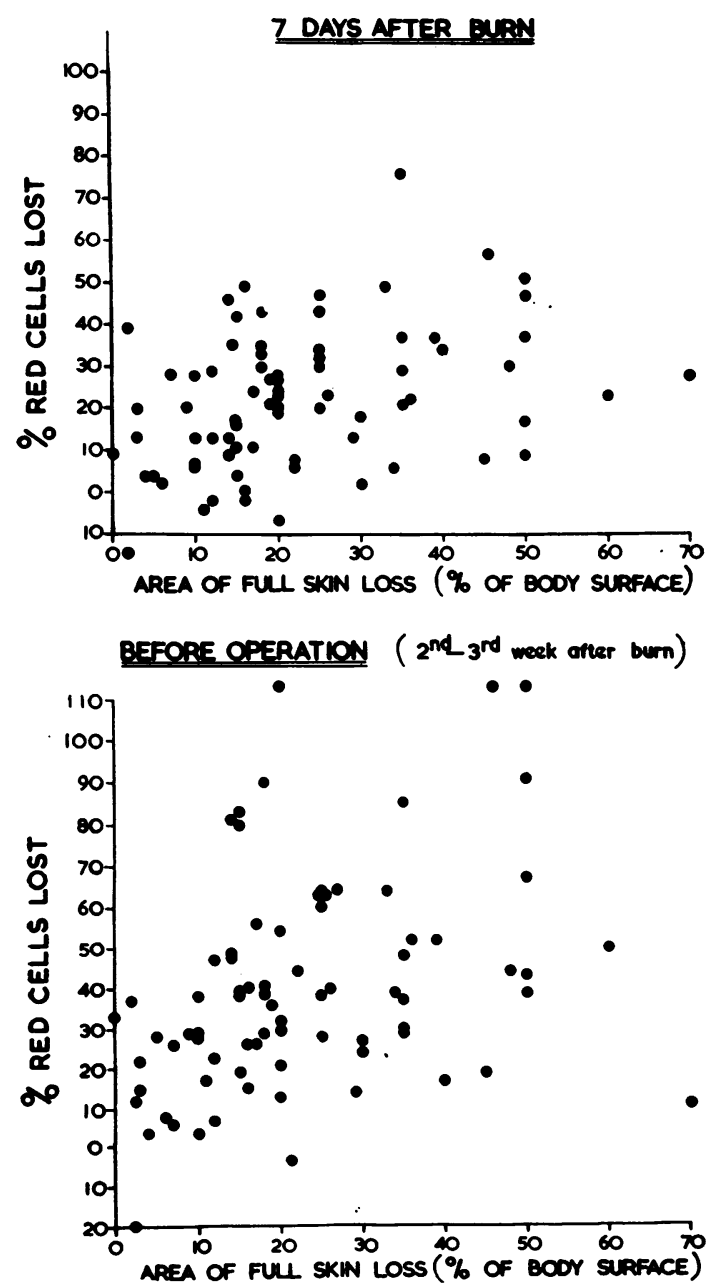

FIG. 5.-Red cell loss, based on peripheral blood findings, between burn and first operation related to area of full-thickness skinloss ( 74 cases).
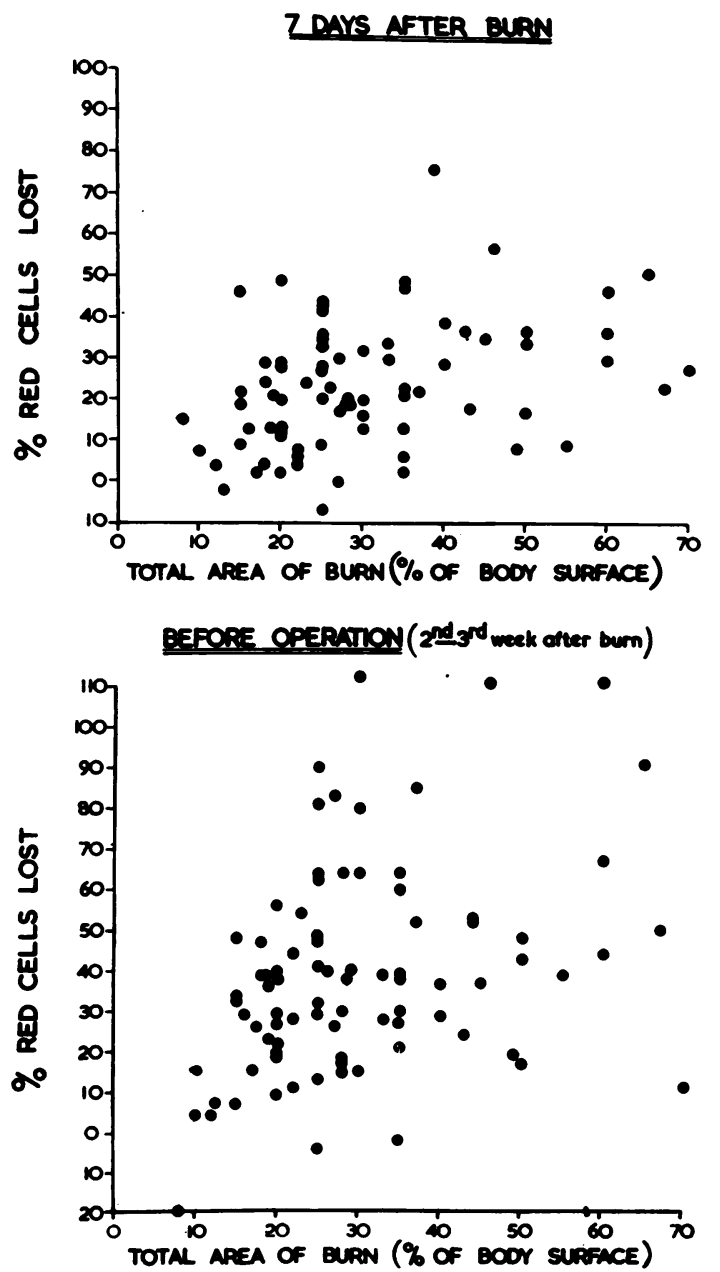

FIG. 6.-Red cell loss, based on peripheral blood findings, between burn and first operation related to total area of burn ( 74 cases).

(2) Full-thickness skin-loss $15 \%$ or more of body surface: it can be seen from Fig. 5 that only 10 out of 54 patients had red cell loss of less than $25 \%$ from burn to operation. Thirty-two out of 54 patients showed red cell losses of 20 to $60 \%$. Fourteen out of 54 patients had greater losses $(60-115 \%)$ of red cells that necessitated repeated blood transfusions before operation. These 14 patients could not be differentiated clinically from the other cases that lost less red cells, but were detected by repeated haemoglobin tests. On the basis of this data a blood transfusion equivalent to 20 to $40 \%$ of the patient's normal red cell volume is given during shock treatment to burns with more than $15 \%$ of full-thickness skin-loss, and the need for further transfusion is checked by haemoglobin tests. 
Total Area of Burn.-Fig. 6 is a scatter diagram showing the relationship between the estimated total area of the burn and the red cell loss between burn and operation. It can be seen that burns of total area less than $20 \%$ often showed a red cell loss of less than $25 \%$ of the red cells and may therefore not require a blood transfusion before operation. Larger burns often lost enough red cells to necessitate a blood transfusion equivalent to $40 \%$ of the normal red cell volume before operation.

Timing of Blood Transfusion Equivalent to $40 \%$ of Normal Red Cell Volume.-We have accepted the desirability of reducing as far as possible the number of blood transfusions, partly because of shortage of veins when limbs are burned and partly to prevent waste of blood. In many children a transfusion of less than $40 \%$ of the blood volume involves using only a fraction of a $500 \mathrm{ml}$. bottle of blood. Against this background we have concluded as described above that a blood transfusion of $40 \%$ of the normal red cell volume will be required in most patients with burns involving more than $15 \%$ of full-thickness skin-loss. Such a large early transfusion theoretically has possible disadvantages as well as advantages. A controlled trial was therefore carried out in which half the patients had a transfusion " early," that is immediately careful and complete typing and cross-matching had been carried out, of 30 to $40 \%$ of the normal blood volume for the age ( 21 cases). The other half did not receive such a blood transfusion until the haemoglobin had fallen to $20 \%$ below normal ("late," 18 cases).

Patients who on admission were considered to have less than $10 \%$ or more than $40 \%$ of fullthickness skin-loss were excluded from the trial, as the former often never require blood and, as described below, the latter were considered to need it during the shock stage. Whether the blood was to be given early or late was decided from a prearranged list in which the deciding factor was the hospital number allotted in the receiving station before admission to the Burns Unit.

Table I summarizes some of the findings and Fig. 3 shows the areas of full-thickness skin-loss, blood transfusions, and haemoglobin charts of the first 30 cases in the trial. The two series of patients proved comparable as regards age and areas burned. This very small controlled trial showed no overriding clinical advantage of replacing the red cell loss early. The expected and actual mortality was similar in the two series. There were two cases of septicaemia among the patients
TABLE I

RESULTS OF CONTROLLED TRIAL OF “EARLY” AND "LATE" BLOOD TRANSFUSION

\begin{tabular}{|c|c|c|}
\hline Blood transfusion $\quad \ldots$ & “Early" & "Late" \\
\hline Number of patients ... & 21 & 18 \\
\hline $\begin{array}{l}\text { Mortality: } \\
\text { Expected from age and area } \\
\text { Died } \\
.\end{array}$ & $\begin{array}{l}3 \cdot 7 \\
3\end{array}$ & $\begin{array}{l}3 \cdot 1 \\
2\end{array}$ \\
\hline $\begin{array}{l}\text { Blood transfusions before } \\
\text { operation: } \\
\text { Total transfusions required } \\
\text { Mean volume per patient, } \\
\text { expressed as \% normal } \\
\text { blood volume .. }\end{array}$ & $\begin{array}{l}28 \\
44 \%\end{array}$ & $\begin{array}{l}18 \\
40 \%\end{array}$ \\
\hline Peripheral blood trend & $\begin{array}{l}\text { Initial polycyth- } \\
\text { aemia, devel- } \\
\text { oping later } \\
\text { anaemia }\end{array}$ & $\begin{array}{l}\text { Initial normality, } \\
\text { developing } \\
\text { early anaemia }\end{array}$ \\
\hline 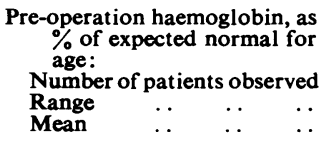 & $\begin{array}{l}20 \\
86-134 \% \\
100 \%\end{array}$ & $\begin{array}{c}18 \\
81-124 \% \\
98 \%\end{array}$ \\
\hline 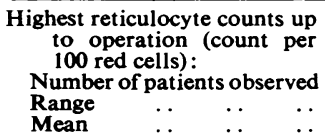 & $\begin{array}{c}16 \\
0 \cdot 8-6 \cdot 0 \\
2 \cdot 7\end{array}$ & $\begin{array}{c}15 \\
1 \cdot 4-6 \cdot 7 \\
3 \cdot 3\end{array}$ \\
\hline
\end{tabular}

receiving blood late (total area $30 \%$ and $55 \%$ of the body surface) and none among those receiving blood early, but the numbers of cases are too small to say that this could not have occurred by chance alone. The pulse, temperature, and respiration were similar in the two series if one excludes the two cases of septicaemia. The biochemical abnormalities of the anaemia as reflected in the serum iron, the iron-binding capacity, and the erythrocyte protoporphyrin content were on the average not significantly different in the two series, nor was the mean cell haemoglobin or the mean cell diameter. Individual children, however, given blood late did show a greater drop in mean cell haemoglobin and in serum iron than observed in any case given blood early.

The possible practical advantages of giving blood late was that polycythaemia was avoided and some saving obtained in the number of blood transfusions required. It can be seen from Fig. 4 that two "late" patients $(3 \%$ and $12 \%$ fullthickness skin-loss) never required a blood transfusion, and from Table $I$ that 28 transfusions were given to 21 patients given blood early and only 18 transfusions to 18 patients given blood late. The total volume of blood transfused and the preoperative haemoglobin levels obtained were not very different in the two series. Although it is theoretically likely that the rate of red cell formation was greater in patients given blood late, the 
difference in reticulocyte count in these cases was not significantly higher statistically than in the early cases.

On balance therefore we found in this small series of cases no important advantage or disadvantage of giving blood early to patients with less than $40 \%$ burns. Our guess is that those who did not lose more than $20 \%$ of their red cells during the shock stage might well have blood late ; those who did lose more than $20 \%$ of their red cells would be better for having it early. We have learnt that patients with less than $20 \%$ burns are unlikely to suffer this loss; the difficulty is to define beforehand which of the patients with burns involving a total area of more than $20 \%$ (or $15 \%$ of full-thickness skin-loss) will suffer this loss of blood.

Guide to Red Cell Loss During Shock Stage.The greatest single factor in the production of burns shock is the loss of "plasma," and the rate of loss becomes critical when the burn is more than about $10 \%$ of the body surface in a child, or $15 \%$ in an adult, excluding erythema. The aim of treatment is to keep the blood volume normal by replacing the plasma loss as it occurs. If the red cell volume remains constant, the haematocrit will reflect the balance between the plasma lost and transfused, and it can in fact be used to measure the degree and rate of the loss from hour to hour. If, however, red cell loss is occurring the blood volume may fall while the haematocrit does not. Replacement of the variable red cell loss must clearly be based on measurement, and the data presented here were collected in an attempt to define how the degree of red cell loss could be assessed during the shock stage and the blood volume accurately controlled.

Degree and Time of Red Cell Loss.-It has been shown (Davies and Topley, 1956) that during the first 12 hours on average only $12 \%$ of circulating red cells are lost after a burn involving 5 to $80 \%$ of the body surface. It is rare for more than $25 \%$ of red cells to disappear in this time ( 1 in 14 cases using the most accurate methods). For this reason we may assume in managing an individual patient that somewhere between 0 and $25 \%$ of red cells has been lost, and that therefore in most cases the blood volume will not fall more than $20 \%$ below normal if the haematocrit is kept at the expected normal for the age. More data are required to check the validity of this assumption, particularly in very extensive (more than $40 \%$ ) burns.

Between 12 and 48 hours after injury clinically important and even massive red cell loss can occur. Fig. 4 is a scatter diagram relating area of burn to extent of red cell loss estimated by a variety of red cell volume techniques. It can be seen that in 11 instances (eight patients) 40 to $70 \%$ of the red cell volume had disappeared.

Red Cell Volume Studies.-These are themselves open to criticism in the shock stage, partly because of the delay in mixing time of any redcell suspension or fluid injected intravenously, partly because of the possibility of very large volumes of "trapped" unmeasured blood, and partly because the patient's normal red cell volume is not precisely known. Our knowledge of the estimated normal red cell volume (Fig. 1) is based largely on other people's reported results (see above). The reliability of red cell volume estimates needs further checking by duplicate and repeated measurements on the same patient, and by comparison of results with other clinical and laboratory evidence. In spite of these limitations the probable value of repeated red cell volume estimations as the only means of measuring clinically important red cell loss when it occurs is shown in cases such as 2, 3, and 4 below.

Area of Burn.-Both the total area and the area of full-thickness skin-loss was not a useful guide for excluding the risk of clinically important red cell loss in patients with burns involving $20 \%$ or more of the body surface. It can be seen from the scatter diagrams (Fig. 4, a and b) that a number of patients with burns even as small as $20 \%$ of the total body surface showed a disappearance of red cells equal to $40 \%$ or more of the red cell volume during the first 48 hours after injury. Red cell volume studies have not been done on many smaller burns at present, but the later haemoglobin levels suggest that much less red cell loss occurs. Losses of more than $50 \%$ of the red cell volume in the first 48 hours have been found so far mainly in burns involving more than $70 \%$ of total area.

Haemoglobin, Haematocrit, and Other Changes in Peripheral Blood.-Peripheral blood findings were of limited value as a guide to clinically important red cell loss during the shock stage. It is uncommon (Case 4) to find a fall in red cell volume to be associated with a fall in haematocrit of a greater degree than that expected from the rates of plasma therapy and expected plasma loss at the time. Further repeated red cell volume studies are required to define this position more clearly.

Free Haemoglobin in Urine and Plasma.-Free haemoglobin, haematuria, or both, has been seen in some burns involving more than $20 \%$ of the body surface, sometimes on admission and often 
again or for the first time during the ensuing 48 hours (Shen and Ham, 1943). The large majority of our cases showing haemoglobinuria have shown a red cell loss ranging from 10 to $25 \%$ during the first 12 hours, and of more than $25 \%$ between 12 and 48 hours after injury. The results demonstrate that clinically serious falls in red cell volume often occur in the first 48 hours in the presence of haemoglobinuria. More investigations are required to know how often red cell loss greater than $25 \%$ of normal can occur in the first 48 hours in the absence of haemoglobinuria. So far we have seen such a loss in only a small minority of cases.

Very Small Red Cells and Fragments Seen in Blood Films. - The morphological changes in red cells have been described in detail by Brown (1946) and Shen and Ham (1943). We have arbitrarily defined a microcyte as any pink-staining cell in a Romanowski-stained film less than $0.3 \mu$ in maximum diameter (Fig. 7). These microcytes have constituted from 0 to $20 \%$ of the cells in the head of a blood film taken within the first few hours after injury. Only a small minority are true spherocytes: most are probably heat-fragmented red cells. Experience on a small number of cases suggested that patients with more than $2 \%$ of microcytes in the blood film on admission frequently developed later haemoglobinuria even if this was absent on admission, and frequently both patient's and transfused cells disappeared to a large extent during the next few days. For this reason our red cell volume studies so far have concentrated on patients showing more than $2 \%$ of

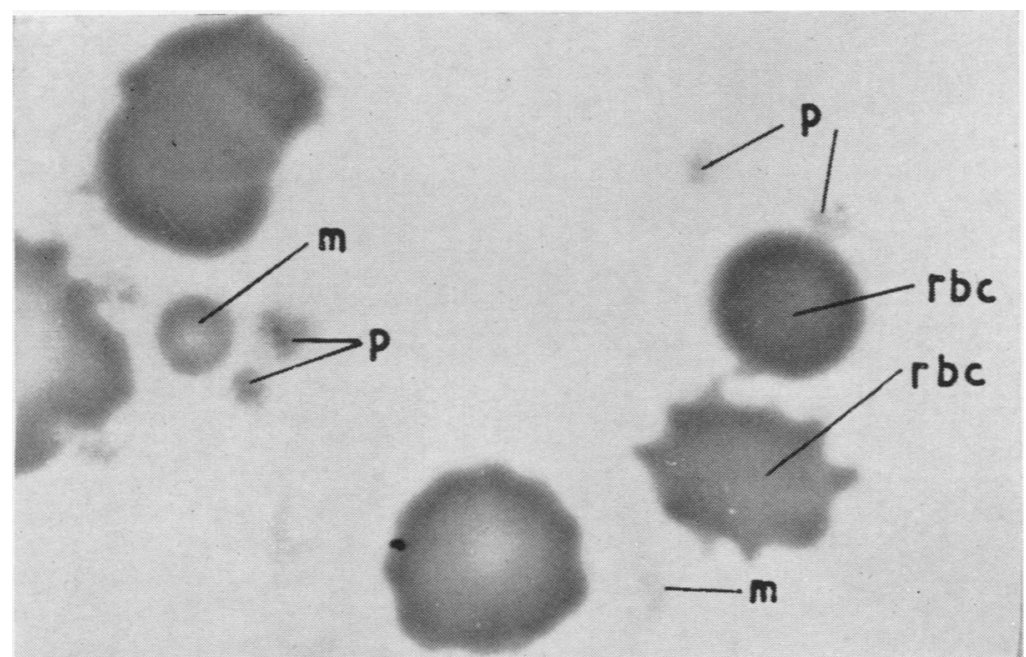

FIG. 7.-Blood film of patient on admission showing " microcytes." $m=$ microcytes; rbc=normal red blood cell; $\mathrm{p}=$ platelets. microcytes on admission. When more than $2 \%$ of microcytes were seen on admission, clinically important (more than $25 \%$ ) red cell loss occurred later in nine out of 13 cases. Red cell losses of more than $25 \%$ of the normal volume have not been found in any of the six patients whose blood film showed less than $1 \%$ of microcytes. But it is too early to be confident that the absence of microcytes entirely precludes the risk of clinically serious red cell loss.

Skin Temperature and Vascular Response to Skin Pressure.-Circulation often appeared normal in patients with a red cell and total blood volume more than $20 \%$ below normal. Only in rare cases, such as Case 4 described below, did a marked increase in skin coldness and pallor develop with the acute red cell loss due to melaena. In some patients a cold skin with poor circulation was present when the blood volume was only some $10 \%$ below normal.

To summarize, in burns involving more than $15 \%$ of full-thickness skin-loss, or $20 \%$ total area, red cell volume studies appear to be the only way of checking that the red cell volume does not fall more than $20 \%$ below normal during the 48 hours after burning. At the present time the presence of haemoglobinuria, or more than $2 \%$ of microcytes in the head of a blood film, or a burn involving more than $50 \%$ of the body surface, are regarded as a special indication for such red cell volume studies.

Case records to illustrate the significance and practical application of these guides to red cell loss are given below: they show how haematocrit and blood volume estimations can be combined in controlling the patient's blood volume. The cases are presented in order of increasing severity and show increasing clinical evidence of serious red cell loss.

\section{Illustrative Cases}

Case 1.-An 11-year-old girl received a $16 \%$ burn of both legs and buttocks when her clothes were set alight : $14^{\circ} \%$ of the body surface was full-thickness skin-loss. (Her height was $130 \mathrm{~cm}$. and average normal values for this height were: blood volume (B.V.) 1.85 litres; red blood cell volume (R.B.C.V.) 0.67 litres; body haematocrit 


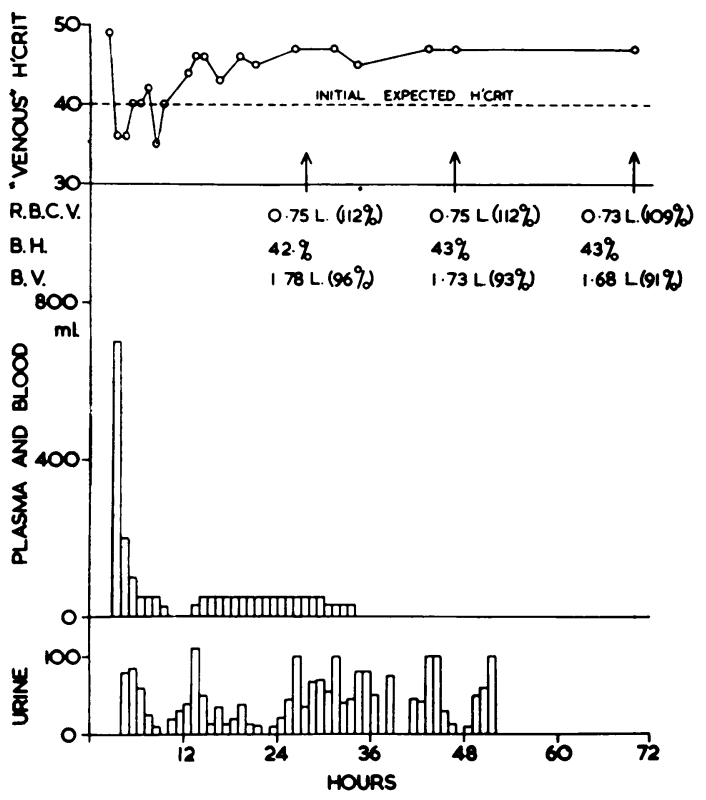

Fig. 8.-Case 1, 11 years; $16 \%$ burn. No microcytes on admission blood film.

(B.H.) $36 \%$; venous haematocrit (V.H.) $40 \%$.) Fig. 8 illustrates the findings.

On account of the size of this burn serious red cell loss in the shock stage was unlikely, although a watch was kept for signs of it.

The first venous haematocrit estimation two hours after injury was $49 \%$ : this corresponds with a body haematocrit of $44 \%$. Using the average red cell volume figure for her height $(670 \mathrm{ml}$.) and assuming no red cell loss, her blood volume at this time was 1.52 litres, which is equivalent to a plasma loss of $330 \mathrm{ml}$. This rate of loss was therefore $165 \mathrm{ml}$. an hour. Three times this hourly loss of plasma $(500 \mathrm{ml}$.) should have been given in the third hour to restore the haematocrit to normal. Actually $700 \mathrm{ml}$. was given with consequent lowering of the haematocrit below normal.

For the first 10 hours an attempt was made to keep the blood volume and the haematocrit around normal; after this the venous haematocrit was allowed to rise to $45 \%$, which theoretically should have reduced the blood volume to $90 \%$ of normal, an oligaemia for which the body can easily compensate. However, a red cell volume estimation at 24 hours showed the red cell volume a little higher than the expected average $(112 \%)$ and the blood volume virtually normal $(96 \%)$.

The plasma transfusion was stopped at 34 hours. after 1.890 litres had been given. During this time the average urinary output since injury was $40 \mathrm{ml}$./ hour.

This case illustrates the routine methods of blood volume control. In the smaller shock case with less than $15 \%$ full-thickness skin-loss serial haematocrit estimations are a good clinical guide to the blood volume, the error being probably less than $20^{\circ}$. They should be used in conjunction with the urine output, and, in patients over the age of 10 years, with the rough formula that 1-1 $\frac{1}{2}$ litres of plasma will be required for each $10 \%$ body surface area burned.

Case 2.-A 4-year-old girl received a $46 \%$ burn of the trunk and legs when her nightdress caught fire: $40 \%$ of the body surface was full-thickness skin-loss. (Her height was $105 \mathrm{~cm}$. : average normal values for this height were: blood volume 1.25 litres; red blood cell volume 0.44 litres; body haematocrit $35 \%$, and venous haematocrit $39 \%$.) Fig. 9 illustrates these data.

Two hours after burning a plasma transfusion was started, and the haematocrit, which was $47 \%$, was brought down to normal over six hours. During this time a blood film showed a moderate number of microcytes and she produced $350 \mathrm{ml}$. of bloodstained vomit. She was then given $500 \mathrm{ml}$. of blood (about $40 \%$ of the blood volume) in the next two hours. Assuming that none of the red cells were destroyed this transfusion would have increased the red cell volume to 0.60 litres, and when the blood volume was normal the body haematocrit would be $48 \%$ and venous haematocrit $53 \%$.

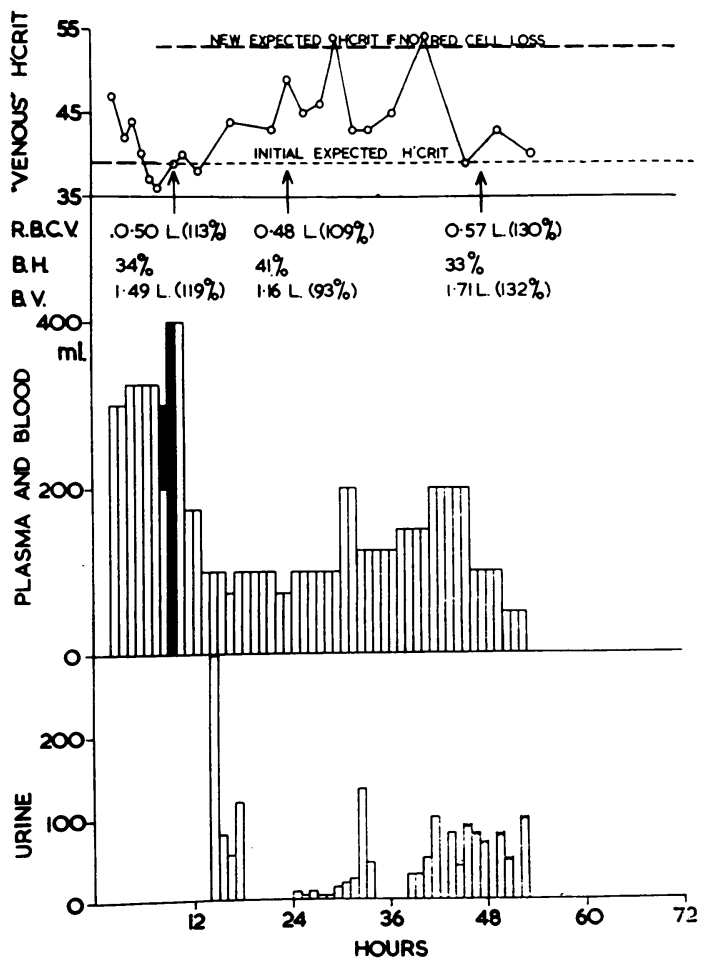

Fig. 9.-Case 2,4 years; $46 \%$ burn. Microcytes on admission blood film. 
The red cell volume estimate at the end of transfusion was 0.50 litres, showing there had been a loss of $25 \%$ of red cells by 10 hours. Accordingly an attempt was made to keep the haematocrit around $44 \%$, the figure corresponding to a red cell volume of 0.50 litres and a normal blood volume. A second red cell volume estimate at 24 hours showed only a slight further fall in red cell volume, showing that the serial haematocrits had proved a useful guide to plasma therapy.

It seemed that an unusually large amount of plasma was required in this case, and attempts were made during treatment to reduce the rate of administration. This resulted in a transient rise of haematocrit and oliguria, and it was therefore assumed that this case required more plasma than normal. A third red cell volume estimation at 48 hours actually showed a raised figure ( 0.57 litres), which could be due to a mobilization of about $20 \%$ more red cells. The transfusion was finally stopped at 53 hours, after giving 8 litres of plasma and $500 \mathrm{ml}$. of citrated blood. The serial haematocrit findings and the blood volume estimation at 48 hours (132\% of normal) both suggested over-transfusion in the last eight hours of plasma therapy.

Further progress was uneventful: after two grafting operations the burn was finally healed in $\mathbf{8 0}$ days.

This patient lost $25 \%$ of her red cells during the first 12 hours after burning and lost little later; this is in contrast to some other patients who lost a considerable amount later (Case 4). The first blood volume measurement was a guide to the correct level at which to keep the haematocrit $(44 \%)$, and the later serial haematocrits proved useful in giving sufficient colloid to maintain a normal blood volume. It may be that more plasma is required than is used in common practice to-day if a normal blood volume is to be preserved throughout the shock stage, but whether it is clinically desirable to maintain a normal blood volume by giving more plasma is as yet unproved. An unexplained rise in red cell volume and of blood volume during the second or third day occurred in this and other patients. Although not evident in this patient, the possibility exists that the hypervolaemia may cause serious cardiac embarrassment.

Case 3.-A 10-year-old girl received a $65 \%$ burn of her trunk, arms, and legs when her frock caught alight from an unguarded fire: $60 \%$ of the body surface was full-thickness skin-loss (Fig. 10). (Her height was $129 \mathrm{~cm}$. ; average normal values for this height were: blood volume 1.80 litres; red blood cell volume 0.65 litres; body haematocrit $36 \%$; venous haematocrit $40 \%$.)

Forty minutes after burning the haematocrit was $46 \%$ and it was brought below normal within an hour by $800 \mathrm{ml}$. of plasma. During the following hour. while the haematocrit was kept steady, catheterization revealed haemoglobinuria, a blood film showed a moderate number of microcytes, and the extremities remained cold: all evidence therefore

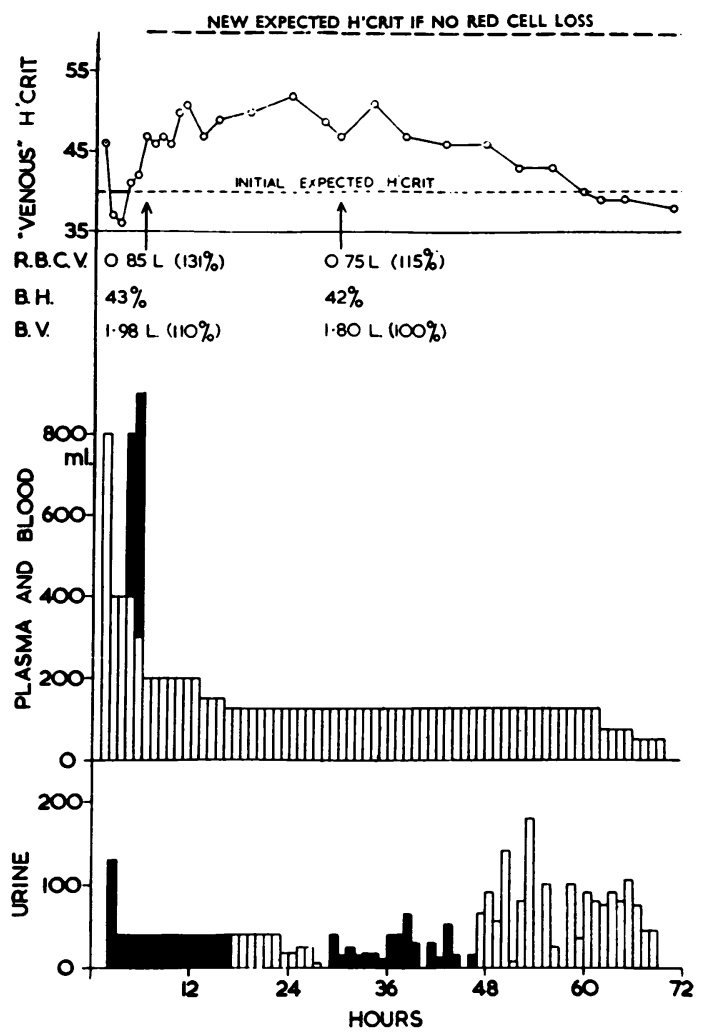

Fig. 10.-Case 3, 10 years; $65 \%$ burn. Microcytes on admission blood film.

pointed to some red cell destruction. One litre of blood was given (equivalent to about $50 \%$ of the red cell volume), together with more plasma to maintain the plasma volume. This would be expected to raise the red cell volume to 0.98 litres if there was no red cell destruction, and when the blood volume was normal the body haematocrit would be $55 \%$ and the venous haematocrit $60 \%$.

A blood volume estimation at the end of the blood transfusion six hours after injury showed the red cell volume to be 0.85 litres ( $131 \%$ of normal); the body haematocrit was $43 \%$ and the blood volume 1.98 litres (110\% of normal). There had been a loss of $20 \%$ of the patient's own red cells.

Haemoglobinuria continued till 17 hours and then cleared, but it returned a second time from 29 to 47 hours before finally ceasing.

Following the blood transfusion and red cell volume estimation an attempt was made to keep the haematocrit around $47 \%$, which was the expected figure to fit in with the measured $20 \%$ loss of red cells and a normal blood volume. But at 30 hours a second blood volume estimation was indicated when haemoglobinuria reappeared.

This second estimate showed a red cell volume of 0.75 litres ( $115 \%$ of normal), and, since the body 
haematocrit was $42 \%$, the blood volume was about 1.80 litres (normal). In other words, by 30 hours the red cell loss had increased to $36 \%$.

It is usually possible to terminate the plasma transfusion at 36 to 48 hours without oligaemia resulting. but in this case it was continued, as a further red cell loss was considered possible. A third red cell volume estimation was made at 76 hours and showed there had been no further red cell loss since the second estimate at 30 hours, but the blood volume had been raised $20 \%$ above normal by unnecessarily. prolonging plasma therapy.

By the tenth day a red cell volume estimate showed that there had been $70 \%$ loss of circulating red cells. On the twelfth day the child was grafted with autografts and homografts, but her condition gradually deteriorated and she died on the sixteenth day.

An important feature of the shock stage of this child was the serious red cell destruction within six hours of injury, with further loss in the next 24 hours.

The first red cell volume measurement enabled the haematocrit to be set at the correct level to obtain a normal blood volume. The second confirmed that regulation of the plasma therapy by the haematocrit did, in fact, maintain a near normal blood volume. The third blood volume estimation confirmed the haematocrit evidence that too much plasma had been given, and in retrospect it appears that the transfusion might well have been stopped at 48 hours. An unusual feature of the shock stage was that the blood volume was maintained at or above normal instead of being allowed to fall somewhat below normal, as it commonly does in extensive burns. A peculiar and possibly associated feature of the post-mortem examination was the absence of diffuse distal tubular necrosis, which is almost invariably seen after such a large burn (Sevitt, 1956a).

Case 4.-A boy, aged 4, received a $70 \%$ burn of the whole trunk and both arms and legs when his nightdress caught alight; almost all the burn was full-thickness skin-loss. (His height was $104 \mathrm{~cm}$. ; average normal values for this height were: blood volume 1.2 litres, red blood cell volume 0.42 litres, body haematocrit $35 \%$, venous haematocrit $39 \%$.)

Within four hours of admission the venous haematocrit was brought down from $39 \%$ to $30 \%$ : the aim was to bring the haematocrit a little below normal, because a blood film which had been examined during the time showed gross red cell destruction. During the second four-hour period a transfusion of $620 \mathrm{ml}$. of blood was given (equal to about half his blood volume), together with more plasma. If no red cells $\overrightarrow{\overline{\vec{N}}}$ had been destroyed this transfusion would have raised the red cell volume to 0.63 litres, and when the blood volume was normal the body haematocrit would have been $52 \%$ and the venous haematocrit $57 \%$.

In practice a red cell volume estimation at the end $₫$ of transfusion, eight hours after burning, was $0.66 \%$ litres $(157 \%$ of normal): the body haematocrit was $34 \%$ and the blood volume was therefore 1.92 litres? $(152 \%$ of normal). These results supported the $\overrightarrow{\vec{\omega}}$ haematocrit in showing that too much plasma had been given in the first four hours, and that we had $\rightarrow$ been wrong in supposing that any cell destruction had? taken place by this time.

As treatment continued the rate of plasma transfusion was cut down steadily and the haematocrit $-\overrightarrow{ }$ steadied at around $45 \%$ : the child's extremities were $\frac{0}{5}$ warm and the urine output high. A second red cell volume estimation was made at 14 hours and this 7 was now 0.50 litres $\left(119^{\circ}\right.$ of normal): since the body $\frac{\mathbb{D}}{2}$ haematocrit at the time was $39 \%$, the blood volume $\frac{c}{2}$

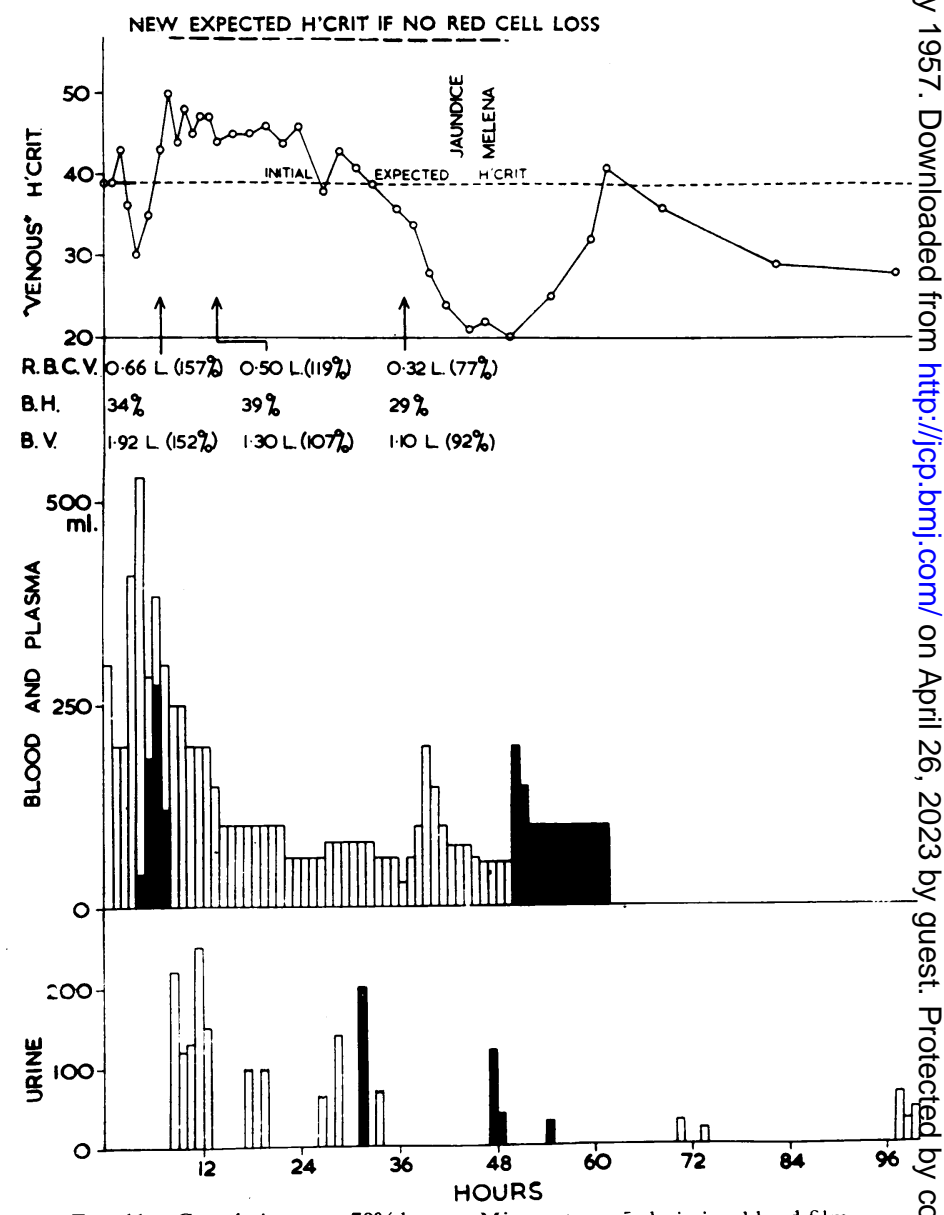

FIG. 11.-Case 4, 4 years ; 70\% burn. Microcytes on_admission blood film. 
was about 1.30 litres (107\% of normal). By this time there had therefore been about a $30 \%$ loss of the patient's own cells, and, in view of the blood volume still being slightly raised, there was an indication to reduce the rate of plasma therapy even further.

Throughout the first three days oral and intravenous non-colloid fluids were given at an average rate of about $60 \mathrm{ml}$. hourly $(1,500 \mathrm{ml}$. a day).

Between 24 and 27 hours the child's haematocrit began to fall steeply, although only a small amount of plasma was being given hourly: at 32 hours haemoglobinuria appeared. These findings were interpreted as internal haemorrhage or a haemolytic reaction, and plasma transfusion was continued steadily to correct the oligaemia till further blood could be crossmatched: this was done with considerable difficulty. At 37 hours massive red cell loss was confirmed by a third red cell volume estimation, which measured 0.32 litres $(77 \%$ of normal); the loss had therefore increased from $30 \%$ of the patient's red cells at 14 hours to $74 \%$ at 37 hours. Since the body haematocrit was $29 \%$, the blood volume was about 1.10 litres (92\% of normal). At 44 hours jaundice became evident and haemoglobinuria was still present ; at 48 hours the child had a melaena.

Between 50 and 62 hours, 2.35 litres of blood was given very slowly, an amount more than the normal blood volume: this succeeded in restoring the haematocrit to normal levels, the jaundice faded, and the haemoglobinuria ceased, but the urine was very scanty and poorly concentrated.

During the fourth day jaundice returned. The child died on the fifth day, and post-mortem examination revealed basal cerebral haemorrhage and jaundice. There was diffuse distal tubular necrosis (lower nephron nephrosis) (Sevitt, 1956a), possibly due to the period of oligaemia.

An important feature of this case is the time of red cell destruction: in contrast to Case 2 the major loss was after 24 hours, and almost none before eight hours. This illustrates the variation from case to case. During the early hours of treatment the haematocrit suggested over-transfusion, but this information was not acted upon until it was confirmed by a blood volume figure: this reluctance to follow the haematocrit findings in the case of a very extensive, deep burn, in which gross red cell destruction was expected, proved mistaken. Finally, this case illustrates how massive the red cell loss can be when internal breakdown of red cells is combined with haemorrhage.

\section{Red Cell Loss During Operation}

Those who are used to treating very extensive burns will agree that steady deterioration of the patient's general condition is still the rule during the first three weeks after injury, whatever the treatment and in spite of all supportive measures. Our aim in treating these cases has been to start and continue the necessary skin grafting operations with as little delay as possible so that the burn wound is closed at the earliest moment. This has usually involved stripping off the granulations and adherent slough by rapid blunt dissection during the third week, rather than waiting for the granulating surface to become clean by natural processes a week or two later. Haemostasis is secured by elevation, pressure, hot packs, and ligatures.

The pre-operative preparation of the patient has included ensuring a haemoglobin of over $80 \%$ of normal, and having sufficient homologous blood cross-matched to satisfy all reasonable likelihood of operation loss. The transfusion must, of course, be running satisfactorily before the operation is started when such a large loss is expected. We have shown that the pre-operative blood volume is on average normal during the third week.

Daily Post-operative Haemoglobin.-Blood loss at operation unreplaced by blood transfused is reflected in a falling haemoglobin during the ensuing three days. We have found the haemoglobin fall one and three days after operation a useful clinical guide, although in rare instances the haemoglobin may continue to fall steeply for more than three days.

The Area Grafted.-The amount of blood lost at operation has been measured by the changes in the peripheral blood in 75 patients, and it has been compared with the proportion of the body surface prepared and grafted (Fig. 12). Two striking features appear from this comparison. The first is that the volume of blood lost at operation is often surprisingly great, and its measurement and replacement are therefore very important. The second is the wide variation in the amount of blood loss in patients undergoing similar grafting pro-

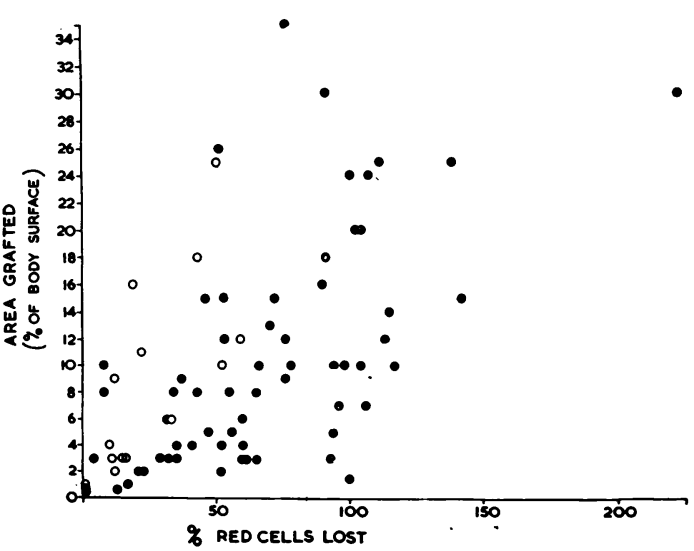

FIG. 12.-Blood loss during operation, based on later peripheral blood findings, related to area grafted (75 operations). Children. $\bigcirc$ Adults. 
cedures, and this makes the area to be grafted a poor guide to the amount of blood which will be lost at the operation. It can be seen in Fig. 12 that an operation to graft $10 \%$ of the body surface involved a blood loss ranging from less than $10 \%$ to $120 \%$ of the normal blood volume.

Age of the Patient.-Fig. 12 also shows how much more blood is lost by children than by adults in grafting the same proportion of the body surface. The blood loss for adults never exceeded $60 \%$ of their blood volume, but the loss in children not infrequently reached $100 \%$, and even $200 \%$ in one case. There seems little doubt that this is due primarily to the greater vascularity of the skin in children, which leads to a much greater loss when grafts are cut and the granulations are removed: in contrast, the elderly have a very avascular skin and may lose no more than an ounce or two when grafts are cut from the whole of both legs.

Site to be Grafted.-On a number of occasions a larger blood loss than usual has been noted when vascular areas such as the face and hands have been grafted in adults. An example is provided by a young man with a $12 \%$ full-thickness burn of the face and hands. Two days before operation he had a normal red cell count. During operation the loss was clearly large and he received five bottles of blood (about $30 \%$ of his normal red cell के volume). During the following four days the $\vec{\circ}$ haemoglobin and red cell count again gradually fell severely, and a further six bottles of blood ( $35 \%$ of the red cell volume) were required to return the red cell count to its normal level.

Assessment during Operation.-The usual clinical criteria for the amount of blood required are nevertheless surprisingly reliable, even with very 웅 large transfusions. Our aim at operation has been to keep up with the blood loss as it occurred. 7 Both surgeon and anaesthetist estimated the visible blood loss, and this amount was given together with about another $250 \mathrm{ml}$. of citrated blood: more than this was only given if the anaesthetist

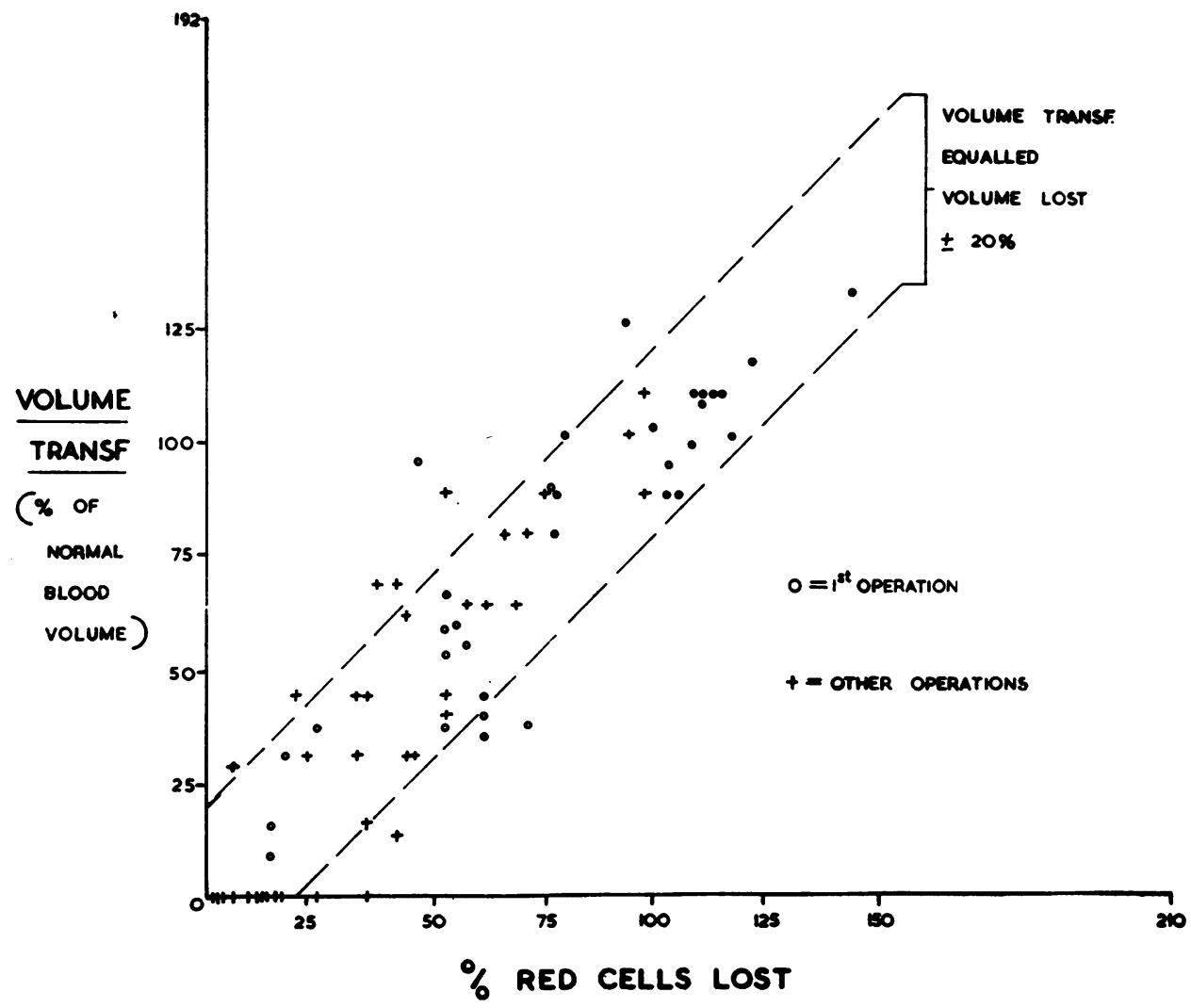

Fig. 13.-Volume of blood transfused during operation related to blood loss based on later peripheral blood findings (69 operations). 
thought that the clinical condition warranted it. A review of 69 operations managed in this way showed that in $80 \%$ of the cases the transfusion given proved to be within $20 \%$ of the blood loss (Fig. 13). In eight patients there was a gain of more than $20 \%$ and in five a deficit of more than $20 \%$.

It was not uncommon for adequately transfused patients to shiver and become cyanosed after the anaesthetic was stopped and they began to regain consciousness. This appearance is deceptive and is not a sign of oligaemia. This may be the body's reaction to the low temperature which is usually present at the end of one or two hours of complete exposure during operation with much of the body surface wet; the rectal temperature has been as low as $90^{\circ} \mathrm{F}$. at the end of such an operation.

Greater accuracy of blood replacement can be obtained by swab weighing. In three patients in whom blood loss was measured in this way, as well as by changes in the peripheral blood, swab weighing underestimated the blood loss by $20 \%$ or less. In our opinion clinical experience makes swab weighing unnecessary for routine operations on patients in the third week after burning, who probably start operation with a normal blood volume. More recently, however, investigation of the value of large primary excisions within six to eight hours of burning has shown that not only is swab weighing valuable but blood volume estimations are necessary before and after operation to ensure a normal pre-operative blood volume and to prevent post-operative oligaemia if there has been internal red cell loss during or after operation. It may be that in time swab weighing will prove sufficient in these cases, but at present the clinical availability of red cell volume estimations at short notice is essential for safety in this procedure. In the few cases when extensive excision and grafting was postponed till about the fourth day, several children tolerated the procedure poorly. Recent blood volume estimations now suggest that the pre-operative blood volume in these cases may have been low with the treatment current at the time. It is probable, therefore, that pre-operative blood volume measurement and swab weighing would be beneficial at this period also.

\section{Red Cell Loss between and after Operations}

At these times the blood loss is very much less than either before the first operation or at the operations themselves (Fig. 2). Scrutiny of the results suggests that in the majority of patients it was absent or minimal and only in a minority of cases does it become clinically important. In detecting these unusual cases with clinically important blood loss, the area of remaining fullthickness skin-loss and the haemoglobin changes are both important as guides to red cell loss.

Area of Remaining Full-thickness Skin-loss.Once skin cover had been obtained for the whole area of the burn, the peripheral blood picture almost always showed a steady return to normality from the slightly high or low values found after the operation. On average (Fig. 2) there was virtually no red cell loss after operation as calculated from the peripheral blood findings.

When complete skin cover had not been attained there was on an average (Fig. 2) a loss of $15 \%$ of circulating cells between all operations. Among patients with less than $2 \%$ of full-thickness skin-loss (Table II) only two out of 34 patients showed falls in red cell count to more than $5 \%$

TABLE II

LOW RED CELL COUNT BETWEEN OPERATIONS RELATED TO AREA STILL TO BE GRAFTED

\begin{tabular}{|c|c|c|c|}
\hline & \multicolumn{3}{|c|}{ Area Still to be Grafted } \\
\hline & $0-1 \%$ & $2-10 \%$ & $\begin{array}{c}\text { More } \\
\text { than } 10 \%\end{array}$ \\
\hline $\begin{array}{l}\text { Red cell count } 80-95 \% \\
\text { Total patients more than } 95 \% \\
\% \text { patients with red cell count } \\
80-95 \% \quad \ldots \quad \ldots\end{array}$ & $\begin{array}{r}22 \\
32 \\
34 \\
6 \%\end{array}$ & $\begin{array}{l}12 \\
24 \\
36 \\
33 \%\end{array}$ & $\begin{array}{c}3 \\
3 \\
6 \\
50 \%\end{array}$ \\
\hline
\end{tabular}

$\chi^{2}$ distribution of cases with $2 \%$ or more to be grafted $=-120$ $(\mathbf{P}<0 \cdot 01)$.

below normal. Among patients with more than $2 \%$ of full-thickness skin-loss, however, one-third showed falls in red cell counts to more than $5 \%$ below normal. In only a minority of these cases did the haemoglobin level fall below $80 \%$ of normal, necessitating blood transfusion. Given that there was more than $2 \%$ remaining full-thickness skin-loss, the exact area was not a useful guide to which patients would show this unusual excessive red cell loss.

Haemoglobin Levels. - In the rare cases showing excessive red cell loss anaemia may last many weeks, and by the policy of never letting the haemoglobin fall below 75 to $80 \%$ of normal the patient may require repeated blood transfusions. Such cases are usually recognized before or after the first operation, and the experience of past haemoglobin results becomes a useful guide to the frequency with which future tests should be carried out. The losses of red cells developed fairly slowly, and could therefore be adequately checked clinically by twice weekly haemoglobin levels. It was unusual, for example, for the 
haemoglobin to fall more rapidly than $1 \mathrm{~g} . \%$ per day. Because of findings such as these it is the policy in this Unit to continue repeated haemoglobin estimations after the first operation until there is less than $2 \%$ of the full-thickness skinloss ungrafted.

\section{DISCUSSION}

If the red cell loss following severe burns is unreplaced it causes an anaemia when haemodilution restores the blood volume to normal. When haemodilution does not occur the loss causes a low blood volume. Both anaemia and oligaemia may contribute to the illness and mortality from burns. During the first few days oligaemia is probably the more common and important clinical factor. The controlled trial of "early" versus "late" blood transfusion described above suggests that in burns of less than $40 \%$ of the body surface anaemia is clinically not important as a cause of illness at this early stage. After the first few days anaemia is more common, but oligaemia may still contribute to the postshock syndrome. Both oligaemia and anaemia can be corrected by blood transfusion soon after they develop provided the blood volume and haemoglobin level are known.

The clinical desirability of giving blood to avoid blood volumes or haemoglobin levels less than $60 \%$ of normal rests on animal experiments and the experience of a clinical practice that is, when possible, avoided to-day. Many workers, including Grant and Reeve (1951), have demonstrated that a blood volume acutely developing and maintained less than $75 \%$ of normal is very often fatal. Our own early experience in burns demonstrated at least three patients where red cell volumes were found to be $50 \%$ below normal, all of whom died. These clinical observations, combined with animal experiments (e.g., Wiggers, 1950), have shown that when the blood volume is maintained below a critical level death occurs from "irreversible shock" or later from renal failure.

The case for not allowing the haemoglobin level to fall to less than $60 \%$ of normal is less dramatic but now fairly well established as clinical practice. It seems likely that a train of clinical hazards, including delayed healing, increased sepsis, pneumonia, and septicaemia, are more common in patients who are allowed to become grossly anaemic (Braithwaite and Moore, 1948).

The optimum level at which to keep blood volume and haemoglobin is much more debatable. We have felt it to be clinically unjustifiable to allow either to fall below $75 \%$ of normal, and our own evidence is therefore based on the treatment of patients whom we have attempted to maintain above this level.

\section{Dangers of Oligaemia}

Our blood volume data suggest that blood volumes $70-90 \%$ of normal are common during the first few days after a severe burn with present resuscitation methods, and that oligaemia may therefore still be contributing to the illness and mortality from burns. Very few patients have so far been treated by us with volumes of plasma or blood that keep the blood volume normal, and it appears that clinical experience of the results of such treatment is very limited. Caution in attempting to return the blood volume to normal is warranted until its advantages and disadvantages are understood.

In hospitals where the mortality from burns is higher than ours (Bull and Fisher, 1954) there is a chance of increasing survival by more careful control of blood volume during the shock stage. The Bull and Fisher figures, however, show little change in the expectation of life of a badly burned patient since 1942 in spite of improvement in control of oligaemia, red cell volume, and many other measures to prevent infection and heal the burn quickly. But it is only in the last year that blood volume studies have been carried out frequently enough (every 12 or 24 hours) to make it likely that oligaemia was really prevented. More data are therefore required to know whether or not mortality can be reduced by more thorough control of blood volume.

Renal damage is another danger of oligaemia. Histological analysis of the kidneys of patients who died after burning has shown that tubular necrosis is frequent and generally can be divided into diffuse and focal types. The diffuse kind is associated with uraemia-either with or without oliguria-whilst the focal type is generally subclinical and unrelated to renal failure (Sevitt, 1956b). Three patients with extensive burns, who died one to three weeks after injury and in whom it had so far been possible to maintain a near normal blood volume with certainty during the shock stage, merely had a focal tubular necrosis and not the diffuse kind which might have been expected from the extent of burning and severity of haemoglobinuria. More data must be collected. but meanwhile it seems possible that significant tubular necrosis and renal failure may be preventable by avoiding oligaemia with more generous plasma and blood transfusion during the first few days after injury.

When early operation to excise and graft a large burn is contemplated it is specially important to 
have the oligaemia fully corrected pre-operatively, otherwise the patient will start the operation in a state of latent or threatened shock. Failure to correct this deficiency may result in the patient collapsing on the table or at best an anxious or hurried operation.

Analogy with other forms of trauma such as limb injuries suggests the manner in which the maintenance of normal blood volume may modify the clinical picture. Clarke and his colleagues (Flear and Clarke, 1955 ; Baar and Topley, 1956 ; Topley and Fisher, 1956) have demonstrated the probable contribution of oligaemia following limb injuries to salt and water retention, to abnormal nitrogen metabolism, to abnormal haemoglobin metabolism, to temperature, pulse, and the general illness of trauma. The chance that correct blood volume control is a factor of real clinical importance in extensive burns is likely enough to warrant detailed studies of the complicated changes that follow these injuries.

\section{Dangers of Anaemia}

The "early" versus "late" blood transfusion trial described above showed that, in burns involving less than $40 \%$ of the body surface, patients allowed to become anaemic to the $80 \%$ level before blood was given were clinically not demonstrably different from those that were transfused early and in whom therefore this degree of anaemia was delayed.

\section{Dangers of Blood and Plasma Transfusion}

Our own results support the evidence of many others, that the risks of transfusion of small volumes of blood are not great but must always be borne in mind (Mollison, 1951). Thrombophlebitis was the greatest single risk of plasma and blood transfusion where the drip had to be run for many hours or days. Cardiac overloading immediately after blood transfusion was very rare indeed, either during the "early" transfusion of blood or later when anaemia developed: it has been seen by us once only, when blood had been given rapidly in the presence of an already high blood volume 10 days after injury.

The risks and disadvantages of transfusing the very large volumes of plasma and blood sometimes necessary to maintain a normal blood volume and composition have to be considered seriously, for the risks of this procedure have yet to be defined. If more red cells are transfused than have disappeared the haematocrit and viscosity of the blood both rise. Because of the con- tinual leak of plasma, enormous volumes of plasma may have to be given to maintain a normal blood volume. Some patients, especially those with burns involving $15-50 \%$ of the body surface, show an unexplained rise in measured red cell volume 24-72 hours after injury. If the blood volume has been maintained at normal up to this time there may be a hypervolaemia subsequently. We have seen possible signs of cardiac overloading during the third to fifth day after injury as evidenced by dilated heart, cardio-respiratory failure, and death. It is not possible to say whether such cases were caused by a policy of maintaining a normal blood volume by generous plasma and blood transfusions. Also, the larger the plasma transfusion the greater the chance of hepatitis. These risks must be weighed against the advantages of maintaining the near normal blood volumes discussed above.

During operation, when more than one blood volume of citrated blood has had to be transfused rapidly, e.g., over two hours, cardiac arrest has occurred. We have felt that this complication may possibly have been associated with the amount of citrate in the blood, and our practice now is to avoid unduly rapid rates of transfusion and to give $5-10 \mathrm{ml}$. of calcium gluconate intravenously if citrated blood amounting to a whole blood volume or more is given within an hour (Mollison, 1951).

\section{Economy of Blood}

Blood can be saved by delaying transfusion until severe anaemia develops. Deliberately letting the haemoglobin fall below $80 \%$ does conserve blood, and frequently the haemoglobin will cease to fall at a level somewhere between $65 \%$ and $80 \%$ of normal. In a hospital where blood is available, however, we feel, as described above, that such treatment is unjustifiable.

If we are seeking the optimum treatment for the individual we do not think that blood is wasted by using it to keep the haemoglobin above $80 \%$ of normal. Economy in the use of veins is frequently of major importance to the patient, and it is therefore sometimes beneficial to transfuse $40 \%$ of the blood volume when the haemoglobin is $80 \%$ below normal, so as to raise it to $120 \%$ of normal and thereby delay the time of the next transfusion.

Blood may be saved by avoiding complications such as acute infection which cause further loss of red cells, and also by early operation. Several days' delay in grafting a large burn results in a further red cell loss associated with the ungrafted area. 
Much of the operation loss is due to removing the granulations by rapid blunt dissection and making the recipient area ideal for grafting. Grafting could probably be done as well by delaying it for a further two weeks or so, and preparing the surface of the granulations with frequent dressings during this time: it is our impression, however, that this delay carries a morbidity and mortality greater than the risk of giving more blood at an earlier operation, but there might be indications for this alternative course if citrated blood was in short supply.

\section{Clinical Management from Injury to First Operation}

When the rationale for keeping the blood volume normal is examined it must be admitted that we are not sure that some degree of oligaemia is harmful ; conversely, we are not sure that keeping the blood volume normal at the price of using more plasma and producing more oedema is beneficial. However, prevention of more than a $20 \%$ reduction in blood volume seems a reasonable aim. If this is so, it is not sufficient to appreciate that a large red cell loss may have occurred and to give an amount of blood based on the extent of deep burning. The wide variation in degree and time of the loss has been described and illustrated above, and control of the blood volume in extensive burns must depend on serial red cell volume and haematocrit measurements if temporary oligaemia is to be prevented. This is an ideal and a standard which can only be reached at present in a burns unit where blood volume estimations can be made at short notice and as part of a 24-hour service. It is quite wrong, however, to conclude that we may be satisfied without this guide. It is in cases with extensive burns which have a chance of survival that massive red cell loss occurs most often, and it is the prevention of oligaemia in these cases which is most likely to improve present results. In other words, at the present time we are failing most to appreciate the degree and time of red cell loss where this failure is most serious in its results.

But to offer no clinical guide to the likely need for blood when the red cell volume cannot be measured would be unrealistic. The following is suggested as a practical clinical guide based on the common types of burns which have been followed with red cell volume measurement. Some overlapping of the groups is inevitable if total area and full-thickness skin-loss are both considered; for this reason the total area of the burn is used as the principal guide.
1. Less than $10 \%$ total area (especially with less than $2 \%$ full-thickness skin-loss); blood transfusion and serial haemoglobin estimations are not called for as a routine.

2. Ten to twenty per cent. total area (usually with $2-10 \%$ full-thickness skin-loss); early blood transfusion is probably unnecessary, but serial haemoglobin estimations are indicated every two or three days until less than $2 \%$ full-thickness skinloss remains unhealed.

3. Twenty to forty per cent. total area (usually 10-30\% full-thickness skin-loss); a blood transfusion equal to $20 \%$ of the patient's blood volume should be given in the first 12 hours and the haematocrit kept between $10 \%$ and $20 \%$ above normal for the patient's weight and height, assuming $0-10 \%$ red cell loss. A further $20 \%$ should be given in the next 36 hours if indicated clinically by oliguria, cold extremities, cyanosis, haemoglobinuria, or more than $2 \%$ microcytes in the head of a stained blood film on admission. Subsequently, repeated haemoglobin tests are required.

4. Over $40 \%$ total area (usually over $30 \%$ fullthickness skin-loss); $20 \%$ of the patient's blood volume should be given in the first 12 hours and the haematocrit kept at normal for the patient's height and weight, assuming $20 \%$ red cell loss. One should then be prepared to give a further blood transfusion equal to 20 to $60 \%$ of the patient's blood volume in the next 36 hours if indicated clinically. These are the patients in whom serial blood volume estimations are most valuable, provided their practical errors are appreciated. Subsequently, repeated haemoglobin tests are required.

\section{SUMMARY}

Repeated observations have been made on the $\frac{D}{0}$ peripheral blood of 150 patients with burns involving $0-80 \%$ full-thickness skin-loss of the $N$ body surface. Eighty-six patients have had red $N$ cell volume studies.

The findings are used to discuss the ways in $\omega$ which it is possible to assess red cell loss:- 중

(a) During the first 48 hours; emphasis is placed on the acute unexplained and largely unpredictable red cell loss that can occur $12-48{ }_{0}^{\circ}$ hours after injury in burns involving more than $20 \%$ full-thickness skin-loss.

(b) Between burn and operation; emphasis is $\frac{\stackrel{?}{\mathbb{Q}}}{\mathscr{Q}}$ laid on the area of full-thickness skin-loss as $a_{-}$ crude guide, and the need for repeated haemoglobin tests. 
(c) During operation; emphasis is laid on clinical judgment, swab weighing, and the need for post-operative haemoglobin checks.

(d) After operation; emphasis is laid on the continuing fall in haemoglobin that can occur in burns with more than $2 \%$ of full-thickness skin-loss ungrafted.

The desirability of giving very large volumes of plasma and blood to maintain a normal blood volume is critically discussed.

No clinically important difference was found in a controlled trial of " early" versus "late" blood transfusion in 39 "shock cases" of moderate extent.

The red cell volume studies were carried out with the collaboration of Mr. John Davies, B.Sc., Mrs. Ann Foster, Miss Janet Frost, B.Sc., and the clinical staff of the Burns Unit, especially Mr. J. Cason and Dr. Mary Fisher. The haematology has been possible with the assistance of Mr. H. Lilly, A.I.M.L.T., Mrs. M. Evans, A.I.M.L.T., and their technical assistants. The charts were largely prepared by Mrs. M. Evans, A.I.M.L.T. We are indebted to the close cooperation of all these colleagues, and especially to Dr. S. Sevitt and Dr. W. Weiner, of the hospital and regional blood transfusion services.

\section{REFERENCES}

Baar, S., and Topley, E. (1956). Acta med. scand., 153, 319. Baronofsky, I. D., Treloar, A. E., and Wangensteen, O. H. (1946). Surgery, 20, 761 .

Berkow, S. G. (1924). Arch. Surg. (Chicago), 8, 138.

- (1931). Amer. J. Surg., 11, 315.

Braithwaite, F., and Moore, F. T. (1948). Brit. J. plast. Surg., 1, 81. Brines, J. K., Gibson, J. G., and Kunkel, P. (1941). J. Pediat., 18, 447.

Brown, A. (1946). J. Path. Bact., 58, 367.

Bull, J. P., and Fisher, A. J. (1954). Ann. Surg., 139, 269.

Chaplin, H., and Mollison, P. L. (1952). Blood, 7, 227.

Clarke, R., Topley, E., and Flear, C. T. G. (1955). Lancet, 1, 629.

Cope, O. (1947). Surg. Gynec. Obstet., 84, 999.

Davies, J. W. L., and Topley, E. (1956). Clin. Sci., 15, 135.

Flear, C. T. G., and Clarke, Ruscoe (1955). Ibid., 14, 575.

Gibson, J. G., and Evans, W. A. (1937). J. clin. Invest., 16, 317.

Grant, R. T., and Reeve, E. B. (1951). Spec. Rep. Ser. med. Res. Coun. (Lond.), No. 277.

Mollison, P. L. (1951). Blood Transfusion in Clinical Medicine. Blackwell, Oxford.

- and Veall, N. (1955). Brit. J. Haemat., 1, 62.

Moore, F. D., Peacock, W. C., Blakely, E., and Cope, O. (1946) Ann. Surg., 124, 811 .

Reeve, E. B. (1948). Nutr. Abstr. Rev., 17, 811.

- and Veall, N. (1949). J. Physiol. (Lond.), 108, 12.

Russell, S. J. M. (1949). Arch. Dis. Childh., $24,88$.

Seckel, H. (1930). Jb. Kinderheilk., 127, 149.

Sevitt, S. (1956a). Personal communication and Journal of Clinical Pathology, 1956, 8, 279.

- (1956b). Journal of Clinical Pathology, 9, 12.

Shen, S. C., and Ham, T. H. (1943). New Engl. J. Med., 229, 70 t.

Topley, E., and Fisher, M. (1956). Brit. J. clin. Pract., 10, 770.

Wiggers, C. J. (1950). Physiology of Shock. Commonwealth Fund; New York.

Wintrobe, M. M. (1951). Clinical Hematology, 3rd ed. Lea and Febiger, Philadelphia. 